\title{
Reconstruction and Overcommercialization of South Luogu Lane
}

\author{
aLiu Yi-lin, ${ }^{b}$ Huang Yu \\ Department of Construction management, Tsinghua University, BeiJing 100084, China \\ a,bpkcliff5@gmail.com
}

\begin{abstract}
Keywords: Reconstruction of South Luogu Lane district; historical and cultural protection; overcommercialization; economic development
\end{abstract}

\begin{abstract}
The contradictions in the reconstruction of old city are outstanding, and for a long time, the reconstruction thought of large-scale tear-down and reestablishment leads to the damage of the historical and cultural elements in a large amount of cities. However, the block structure and architectural features in the conservation districts of South Luogu Lane district maintain perfect to the maximum, which are in self-improvement and renewal continuously. This provides strong referencial significance for the reconstruction of old city in other districts. This paper reviews the reconstruction process of South Luogu Lane district, makes preliminary discussion and analysis from the economic and political perspectives, and makes initial investigation of the overcommercialization after reconstruction.
\end{abstract}

\section{Introduction}

Beijing has a history of more than 850 years, and it becomes the outstanding representative of feudal capitals with the perfect architectural system in the world with historical value after expansion of several dynasties. The reconstruction mode with the government plays the leading role and the developer as implementation subject has accumulated a large amount of contradictions in the reconstruction process and increased the difficulty of reconstruction. However, during several decades of tear-down and construction, South Luogu Lane district still keeps the previous style and features to the maximum. As the oldest city close to the central axis in Beijing, South Luogu Lane district didn't suffer any irreparable damages; on the contrary, in the modernization tides nowadays, the district with its particular charm integrates into Beijing of high-rise buildings. The reconstruction mode of South Luogu Lane district deserves serious analysis, and the advantages and disadvantages in the reconstruction district are worthy of the reference of descendants.

\section{Analysis of South Luogu Lane district from political and economic perspective}

Lefebvre(1991) points out that "the spacial transformation in cities is the product of politics and strategies"; therefore, politics is one of the necessary elements in the discussion of urban spacial transformation. Thus, this part is going to analyze from economical and political perspectives and explore the reconstruction process of South Luogu Lane district. 1To discuss the influence of politics on cities, it is necessary to make specific divisions on different transformations at different periods. How can South Luogu Lane district keep till today after so many times of large-scale of demolition and reconstruction? The most important is the reconstruction this time is different, as government doesn't play the leading role; the reconstruction mode is worthy of discussion.

From the description of Song Xuan (2010), we can find some clues: after the first-stage project of Juer Hutong, Tsinghua University accepted the entrust of Dongcheng District Government and continued to make investigations on South Luogu Lane district around Juer Hutong, completing Regulatory Detailed Plan of South Luogu Lane District, which is very important for putting forward the regulatory regulations of protection and the scale restriction of reconstruction and development; although there is no protective repair requirement on cultural relics and ancient architectures, there are important effects against the background of that time, and it also lessons the pressure of

${ }^{1}$ Lefebvre.1991 The Production of Space. Oxford: Blackwell. 
reconstruction and development at this district and spares the old city from facing direct shocks in the reconstruction period, saving space for the following culture tourism and small-scale circulation and transformation in advance. 2 From the literature review above, it can be found that the three important periods are very important for the reconstruction of South Luogu Lane:

Reconstruction period of Juer Hutong

The first large-scale rebuild of old city

The second large-scale rebuild of old city.

Thus, this paper will explore the influence of politics and economy on the reconstruction of South Luogu Lane according the the division of these 3 periods.

Reconstruction period of Juer Hutong

From political perspective

In 1978, the Third Plenary Session of the 11th Central Committee of the Chinese Communist Party defines the route of reform and opening up; and the Third Plenary Session of the 12th Central Committee of the Chinese Communist Party confirms the planned commodity economy policy on the basis of public ownership, and starts to deepen the reform of state-owned enterprises, putting forward the market system with various ownership systems, with reform emphasis changing from rural to urban areas (Shao Lei, 2003) Against this background, construction of residence can be seen as government directive plans, a test scheme of reconstruction in the future.

From economic perspective:According to Wu Jing (1990), Beijing Municipal Government chose three places of old and dilapidated houses as pilot projects, which are Juer Hutong in Dongcheng District, Small Warehouse in Xicheng District and Southeast Yard in Xuanwu District. 3According to the economic source data of Wu Jing (1990), a table related to economy can be got.

\begin{tabular}{|c|c|c|c|}
\hline Categories & Juer Hutong & nall Warehouse & Southeast Yard \\
\hline $\begin{array}{l}\text { Reconstruction } \\
\text { mode }\end{array}$ & $\begin{array}{l}\text { Residence cooperation } \\
\text { To be updated }\end{array}$ & $\begin{array}{l}\text { Residential real estate } \\
\text { development }\end{array}$ & $\begin{array}{l}\text { Renovated } \\
\text { housing } \\
\text { construction }\end{array}$ \\
\hline $\begin{array}{l}\text { Financial } \\
\text { resources }\end{array}$ & $\begin{array}{l}\text { From three channels of } \\
\text { personal capital raising, } \\
\text { institution investment, and } \\
\text { state support, with total } \\
\text { investment of } 2.84 \text { million } \\
\text { yuan, where the country } \\
\text { undertakes amount } 1.11 \\
\text { million yuan. }\end{array}$ & $\begin{array}{l}\text { Government provides one } \\
\text { fifth of the total investment, } \\
2.5 \text { million yuan, real estate } \\
\text { management bureau of } \\
\text { Xicheng District pays on } \\
\text { account for another one fifth, } \\
\text { and the rest is filled with } \\
\text { sales sum of public } \\
\text { buildings. }\end{array}$ & $\begin{array}{l}\text { Filled with } \\
\text { government } \\
\text { investment and } \\
\text { sales sum of public } \\
\text { buildings. }\end{array}$ \\
\hline
\end{tabular}

Analyzing from the economic perspective of government, we can find that although the three pilot places are partially subsided by the government, the governmental subsidy for Small Warehouse, compared with Juer Hutong, is obviously less, and it adopts the mode of paying three fifth of the expenditure through building commercially used public buildings, which can greatly help for government reconstruction and finance.

Conclusions:In reference to the large-scale reconstruction of old city, the focus of government at this time is to reduce financial subsidies with which mode to solve the housing demand; the pilot project of Juer Hutong offers a new feasible route for the reconstruction of South Luogu Lane district; the great influence in China and even the world makes the reconstruction of South Luogu Lane get rid of the previous mode of demolish and take the mode of "gradual small scale". This establishes keynote for the reconstruction of South Luogu Lane district.

The first large-scale rebuild of old city

From political perspective

The 1990s is the crucial period for China to change from commodity economic trial to the confirmation of socialist market economy system. To release land resource and attract foreign

\footnotetext{
${ }^{2}$ Song Xuan. 2010 Case study of reconstruction of South Luogu Lane district in Beijing

${ }^{3} \mathrm{Wu}$ Jing.1990 Technological Development and Reform
} 
investment, the state council issued Temporary Ordinance of Sale and Transference of Land Usage Right of State-owned Land in Urban Area, and built the system of paid land use; at the same time, under the active investment promotion, large amount of foreign capital comes to the industry of real estate, driving the increase of national economy directly.

From economic perspective:Since 1992, Beijing has started to invite investment in Hong Kong, Singapore and other oversea regions, sending message of reform and opening-up to the west world, which gives important power for large-scale reconstruction of old city at the same time to realizing the purpose of returning to global economic market. More importantly, at this period, Beijing began to step into frequent and rapid global economic market. (Liu Zhiqiang, 2008)4

According to Beijing Real Estate (1998), we can clearly see that analyzing from economic perspective, a large part of investment in the first large-scale rebuild is foreign investment, connecting China with global economy to a certain degree. At the same time, this will also change under the changes of global economy.

\begin{tabular}{|llll|} 
& $\begin{array}{l}\text { Investment } \\
\text { amount(billion yuan) }\end{array}$ & $\begin{array}{l}\text { Foreign } \\
\text { amount(billion yuan) }\end{array}$ & $\begin{array}{l}\text { investment } \\
\text { investment (\%) }\end{array}$ \\
\hline $\begin{array}{l}\text { Dongcheng } \\
\text { District }\end{array}$ & 8.063 & 4.897 & 60.7 \\
\hline Xicheng District & 2.765 & 2.331 & 84.3 \\
\hline Chongwen District & 3.855 & 3.108 & 80.6 \\
\hline Xuanwu District & 2.37 & 1.282 & 54.1 \\
\hline \multicolumn{1}{|c|}{ Total } & 17.053 & 11.618 & 5 \\
\hline
\end{tabular}

Beijing Real Estate, 1998(10)

Conclusions:In the 1990s, the commercialization system of land became coomplete and capital from Hong Kong and Southeast Asia started to pour into Beijing to the commercial real estate development with the name of rebuild, making the livelihood projects of dilapidated building rescue and danger and difficulty relief transformed into large-scale demolish and real estate development with residents ' removal, bringing severe damage to social relationship, historical landscape and cultural relics and buildings. Luckily, South Luogu Lane, at that time, was not damaged under the protection of Regulatory Plan of South Luogu Lane District, supplying good experience for following reconstruction afterwards.

The second large-scale rebuild of old city

From political perspective

On November 10th, 2001, China joined WTO, starting to develop towards trade liberalization, integrated into world economic system comprehensively. In terms of urban planning, in the 1990s, there are many conflicts between the leap forward development of old Beijing and existed planning, especially the damage of high volume rate on the environment, public infrastructure and urban landscape, as well as the swallowing of Hutongs and traditional yards in old city by real estate developers. Based on this, the overrall planning of Beijing proposed to adjust developing scale, strengthen the construction investment and deepen the protection of historical city.

From economic perspective:After 2000, with the rise of monetization of housing distribution and secondary housing market, China has tentatively built housing consumption financial system, mainly relying on overseas capital; with the gradual establishment of real estate financial system, the real estate finance with national financial system has replaced foreign capital, becoming the main power in housing real estate development in the second large-scale rebuild.

Conclusions:For South Luogu Lane, the success of Olympic Bid causes the rise of protecting cultural and historical relic trend, driving the up-down reconstruction of South Luogu Lane. Although the lag of national historical and cultural protection policy leads the layoff of governmental reconstruction project, with the encouragement of the success of Juer Hutong pilot project, the reconstruction of South Luogu Lane takes place spontaneously among people, among which is the

${ }^{4}$ Lin Yifu, Liu Zhiqiang.2008 Financial Power Division and Economic Growth in China

${ }^{5}$ Beijing Real Estate, $1998(10)$ 
commercialized reconstruction caused by cultural creative industry. The cultural creative industry of South Luogu Lane is benefited from its advantaged geology, history and culture.

\section{Overcommercialization of South Luogu Lane}

The "gradual small scale" renewal of South Luogu Lane district improves the commerce and living environment of this area, and protects the historical and cultural elements to the maximum, which can be called as a big success and worthy of reference. Of course, the self-update of South Luogu Lane has certain limits, which needs unitary planning and rebuild by the government.

In this paper, we want to discuss on the commercialization of South Luogu Lane.

Manifestation of overcommercialization of South Luogu Lane

New problems caused by overcommercialization

This investigation adopts the means of internet survey. To investigate the generation of whether South Luogu Lane can be overcommercialized, we make arrangement on the form-patterns of overcommercialization beforehand, which are 6: endangering the ecological environment of scenic spot, damaging the local culture of scenic spot and its surroundings, influencing the sustainable development of scenic spot, overload reception of space, and cut-throat competition among hotels, and so on. 7

Form-patterns of overcommercialization

\begin{tabular}{|c|c|c|}
\hline & $\begin{array}{ll}\text { Form-patterns } & \text { of No. } \\
\text { overcommercialization } & \end{array}$ & $\begin{array}{l}\text { Formpatterns of No. } \\
\text { non-overcommercialization }\end{array}$ \\
\hline \multirow[t]{4}{*}{ Industry } & Over-dependence on entrance tickets $\quad$ A1 & $\begin{array}{l}\text { Entrance ticket is only one of } \mathrm{B} 1 \\
\text { profit making means }\end{array}$ \\
\hline & $\begin{array}{l}\text { New scientific and technological } \\
\text { industry plays the main role, and local } \\
\text { culture loses }\end{array}$ & Keeps local culture \\
\hline & $\begin{array}{l}\text { Foreign culture plays the main role of } \\
\text { profit making }\end{array}$ & $\begin{array}{l}\text { Foreign culture takes a small B3 } \\
\text { place in profit making }\end{array}$ \\
\hline & Cut-throat competition among hotels & $\begin{array}{l}\text { Fair competition among B4 } \\
\text { hotels }\end{array}$ \\
\hline \multirow[t]{3}{*}{ Landscape } & More and more man made scenic spots & Keep natural landscape $\quad$ B5 \\
\hline & $\begin{array}{l}\text { Commercial signboards focus on } \\
\text { foreign culture }\end{array}$ & $\begin{array}{l}\text { Commercial signboards B6 } \\
\text { focus on local culture }\end{array}$ \\
\hline & $\begin{array}{l}\text { Streets are over transformed mixed with } \\
\text { old and new elements }\end{array}$ & $\begin{array}{l}\text { Keep original street } \mathrm{B} 7 \\
\text { appearance }\end{array}$ \\
\hline \multirow[t]{5}{*}{ Environment } & Venality leads to overload reception & $\begin{array}{l}\text { Many people but not B8 } \\
\text { crowded }\end{array}$ \\
\hline & $\begin{array}{l}\text { Over-exploitation } \\
\text { of scenic spots and management is in } \\
\text { chaos }\end{array}$ & $\begin{array}{l}\text { Proper management in scenic B9 } \\
\text { spots }\end{array}$ \\
\hline & Insufficient facilities & Enough facilities \\
\hline & Too noisy to appreciate the view & Lively but not noisy \\
\hline & Too much rubbish & Clean \\
\hline \multicolumn{3}{|c|}{$\begin{array}{l}\text { These form-patterns are added in this questionnaire and other non-overcommercialization } \\
\text { form-patterns are added. The purpose is to avoid subjective consciousness affecting results and to } \\
\text { reflect real situation according to personal experience. After design, the questionnaire is handed out } \\
\text { in the internet, and } 178 \text { answers are got, and the analysis results are as following: } \\
\text { Questionnaire on the overcommercialization of South Luogu Lane }\end{array}$} \\
\hline & Questions & Form-patterns $\%$ \\
\hline
\end{tabular}

\footnotetext{
${ }^{6}$ Wang Ning.2004 On damages of overcommercialization of and over-tourism of scenic spots

${ }^{7}$ Fan Fangzhou.2005 Analysis on the overcommercialization of scenic spots
} 


\begin{tabular}{|c|c|c|c|}
\hline \multirow[t]{4}{*}{$\begin{array}{l}\text { Impression } \\
\text { industries }\end{array}$} & Various snacks and food of different countries & A3 & 41 \\
\hline & Latest products in Beijing & A2 & 25 \\
\hline & Latest products in foreign countries & $\mathrm{A} 2$ & 23 \\
\hline & Various traditional cultural products in Beijing & $\mathrm{B} 2$ & 11 \\
\hline \multirow{4}{*}{$\begin{array}{l}\text { Impression } \\
\text { landscape }\end{array}$} & Mixed with old and new & A7 & 36 \\
\hline & Antique commerce signs & B6 & 26 \\
\hline & Immersed in the atmosphere of new times in Beijing & A6 & 25 \\
\hline & Old street in Beijing & B5 & 13 \\
\hline \multirow[t]{6}{*}{ Thoughts on visit } & Crowded & A8 & 40 \\
\hline & Dirty & A12 & 32 \\
\hline & Streets too narrow & A8 & 13 \\
\hline & Insufficient facilities (dustbin, washing-room) & A10 & 10 \\
\hline & Too noisy & A11 & 3 \\
\hline & Lively & B11 & 2 \\
\hline
\end{tabular}

From the investigation, it can be found that South Luogu Lane now has showed the form-patterns of overcommercialization in industry, landscape and environment.

1.Historical and cultural elements are ignored. From the impression on industry, it can be seen that most of the interviewees think that the deepest impression in South Luogu Lane is various snacks and food, and the second is the latest products at home and abroad. Beijing traditional cultural products only take $11 \%$. It can be seen that the space for historical and cultural elements of old Beijing is pressed largely, replaced by latest products and food at home and abroad. However, as the commercial advertisements is too much, the influence of cultural creative shops of the main street overrides the historical and cultural charm, making the relics and values of history and culture in this are rarely known. Besides, the nongovernmental folk culture once thriving, such as folk literature and art, instrumental music, entertainment and competition, handicraft art, art and other forms, are impacted by commercialization and close to disappear.

2. Competition of commercial activities in the streets are fierce. From the impression on landscape, it can be seen that, most of the interviewees think the atmosphere of South Luogu Lane is old mixed with old. There are modern cafes and antique sign-boards at the same time, and the age feeling are not coordinate, which cannot make tourists feel old streets of Beijing. The competition within industry is too fierce and there are cut-throat competition means of direct copy of cultural creativity among shops and sales with low price, which shortens the life-cycle of shops, compresses the profit space and lowers the enthusiasm of shops on protecting, inheriting and innovating culture.

3. New problems appear in living environment. From the thoughts on visit, it can be seen that most of the interviewees think it is too crowded, dirty and narrow and other problems of overcommercialization. It shows that from reconstruction till now, the environment problem has become an important issue in South Luogu Lane. In fact, besides the main street, Hutongs in South Luogu Lane district are mainly for ordinary people to live. But the problems of overcommercialization makes South Luogu Lane filled with tourists, mixed with various people; the transportation, sanitation, and safety in Hutongs are faced with great pressure. The shortage of mating of facilities worsens the living environment of South Luogu Lane district.

\section{Countermeasures for overcommercialization}

Reinforce the whole landscape protection, optimize environmental qualities of streets. Reinforce the clear-out and repair of houses in South Luogu Lane district; gradually renovate, rebuild or demolish buildings unsuitable for traditional landscape protection requirements; enhance persistent protection of key cultural relics protection institutions, and keep the living form and spacial features of unique "Hutong - quadrangle courtyard". At the same time, through decentralizing population, improving transportation and completing public facilities, the quality of street environment is 
elevated. The specific measures are: increase the capital and policy support for population decentralization; implement traffic control and enhance traffic management; improve the united design and planning of infrastructure to suit the historical landscape of this area.

Elevate connotation of cultural creative industry, promote industry to develop higher. Culture is the essence of South Luogu Lane district. Presently, although the cultural creative industry in South Luogu Lane has certain scale, the commercialization lessens the cultural connotation greatly. We should actively guide the cultural creative industry to dig out historical and cultural connotations, to highlight cultural features, to enrich cultural creative content, to elevate the taste of cultural creation and to make cultural creative industry inherit and carry forward the historical and cultural essence better. At the same time, we should properly make specifications on the competition of cultural creative industry, protect the originality of cultural creation, beat cut-throat competition, preserve the rights of artists for cultural creation and clarigy practitioners' duties.

Exert the influence of historical relics on the reconstruction of South Luogu Lane. Historical and cultural relic protection site is the important treasure for South Luogu Lane. We should properly introduce tourism, cultural display and other projects to elevate the whole taste of this district according to the location, protection class and cultural features and other elements, to recover the historical and cultural image of this district.

\section{Conclusions}

South Luogu Lane district steps out of the "gradual small scale" reconstruction mode with its special background and in combination with its own advantages and governmental support, and completes its influence of improving living environment, protecting history and culture, and promoting economic development. This has great referential and guiding significance on the old city reconstruction of Beijing and other districts.

In a word, old city reconstruction, especially involving important historical and cultural protection, should obey the historical development, social needs and economic development, and implement gradually from point to surface scientifically. In this process, three parties of government, developer and residents should fully communicate, perform their own functions, restrict each other, to ensure the right direction of reconstruction and make sure the city can realize responsibilities of meeting living needs, continuing history and opening tomorrow, and so on.

\section{References}

[1] Wang Zongli. Report on the Conference of Dilapidated house Transformation of Beijing.1995

[2] Fang Ke. Renewal of Modern Beijing - Investigation, Study and Exploration. 2001

[3] Mumford.1961 The City in History: Its Origins, Its Transformations, and Its Prospects.New York: Harcourt Brace World.

[4] Song Junling, Ni Wenyan translated (2000), History of urban development: origin, evolution and prospect, Chinese Architectural Industry Press.

[5] Lefebvre.1991 The Production of Space. Oxford: Blackwell.

[6] Song Xuan. 2010 Case study of reconstruction of South Luogu Lane district in Beijing

[7] Wu Jing.1990 Technological Development and Reform

[8] Lin Yifu, Liu Zhiqiang.2008 Financial Power Division and Economic Growth in China

[9] Beijing Real Estate ,1998(10)

[10] Lin Yifu. Hu Shudong. 2000 Enter WTO: Chanllenges and Opportunities

[11] Zhao Qiliang. 2002 Study on Problems of Beijing Real Estate from Introducing Foreign Captital to Entering WTO

[12] Zhao Wen. 2009 Exploration on Protection and Rebuild Measures of Urban Historical Landscape of Beijing

[13] Liu Manliang. 2006 Study on Organic Renewal Mode of Gradual Small Scale in Traditional Streets of Beijing

[14] Liang Jialiang. 2007 Study on Evolution of Traditional Yard in Beijing

[15] Shao Lei. 2003 System Structure and its Changes of Protection and Reconstruction of Beijing 
[16] Zhang Fengtai. 1998 Problems and Countermeasures in Urban Housing Demolition 